\title{
Synthesis and Characterization of Nanogold and Nanosilver as Leprosy Drug Candidates and Their Activity Tests in Leprosy Patients; Case Study
}

\author{
Titik Taufikurohmah \\ Chemistry Department \\ Universitas Negeri Surabaya \\ Surabaya, Indonesia \\ titiktaufikurohmah@unesa.ac.id \\ Hari Armadianto \\ Production Department \\ PT. Gizi Indonesia \\ Bogor, Indonesia \\ hari@gizi.co.id
}

\author{
Djodjok Soepardjo \\ Japanese Department \\ Universitas Negeri Surabaya \\ Surabaya, Indonesia \\ dsoepardjo@unesa.ac.id \\ Rusmini \\ Chemistry Department \\ Universitas Negeri Surabaya \\ Surabaya, Indonesia \\ rusmini@unesa.ac.id
}

\begin{abstract}
One of nanogold uses is as a leprosy drug because it has an activity to increase cell proliferation and collagen biosynthesis. These two activities are necessary for the process of recovery and closure of wounds, including in leprosy. Nanosilver can act as anti-bacterial material, including against leprosy bacteria Mycobacterium leprae. This study used a combination of nanogold and nanosilver to treat leprosy. The theoretical application was very suitable and promising optimal results. The question was whether the combination application of nanogold and nanosilver could be used to treat leprosy. The method used in this study was a clinical test applied a combination of nanogold and nanosilver in 30 leprosy patients who still consumed leprosy drugs as the treatment group. Results were compared to 30 other patients who only consumed leprosy drugs as a control group. Data was collected by medical experts every 2 weeks for 3 months as various medical indicators; wound recovery (width and pain), body temperature, blood pressure, heart rate, and skin surface softness. Results showed that patients with treatment using nanogold and nanosilver was healed significantly faster compared to patients in the control group. Thus, a combination of nanogold and nanosilver could be used to accelerate the healing process of leprosy patients.
\end{abstract}

Keywords—nanogold, nanosilver, leprosy drug, recovery, future medicine

\section{INTRODUCTION}

One of the uses of nanogold is as a leprosy drug since it has an activity to increases cell proliferation and collagen biosynthesis [1]. Patients of leprosy experienced continuous tissue damage and even amputation of toes, fingers, arms, legs and thighs. Cellular proliferation and collagen biosynthesis are important in recovery and closure of wounds occurred in leprosy. Nanogold is expected to reduce tissue damage, thus amputation can be prevented. Nanogold possesses antioxidant activity that can reduce free radicals at various damaged tissue sites in the case of leprosy [2], including skin tissue [3, 4]. Nanogold had been used in a number of biopharmaceutical formula, because it was safe for the metabolism process of the body or bioavailable [5], including the metabolism process of the body. Protein biosynthesis is used to build various tissue by using nanogold as co-enzyme [6].

Based on the ability of nanogold in various biological tissue, nanogold can be considered as the material of future medicine [7]. Based on the size and surface chemistry of nanogold, it can conduct cellular interaction, including in mitochondrial organelle [8]. Many interactions of nanogold with cell organelle had been analyzed using atmospheric scanning electron microscopy [9]. The adverse bioeffect of equidimensional nanogold and silver nanoparticles with the complex of innocuous bio-protectors had also been reported [10].

Silver nanoparticles can also be applied as an antimicrobial agent, such as against leprosy bacteria Mycobacterium leprae [11]. This material had a broad spectrum of use, including as an antiviral agent [12]. 
Nanosilver is a non-toxic and safe natural mineral for daily use. The combined minerals also present in groundwater or natural water sources [13]. The combined materials of nanogold and nanosilver as leprosy medicine was theoretically very suitable and promised optimal results [14]. The big question was whether the combined application of nanogold and silver nanoparticles could be applied to treat leprosy?

Stability of colloidal silver nanoparticles had been tested and used in modern cosmetic formulas as an antimicrobial agent [15]. Silver nanoparticles accumulated in the body as free ion and attacked microbes or bacteria [16]. On the other hand, nanogold had been used as an essential material in ointment and external medicine [17]. The production process of silver nanoparticles and nanogold used the bottom-up method or nanomaterial synthesis [18].

This study used 60 patients of leprosy who lived in the Babatjerawat social home, Benowo Surabaya. Patients are divided into two groups randomly contained respectively 30 people. This study applied a combination of nanogold and silver nanoparticles to 30 leprosy patients who still consumed leprosy drugs (treatment group). The other group was leprosy patients who continue to consume leprosy drugs without consuming nanogold and silver nanoparticles (control group).

The research data were synthesis results, the characterization, and nanogold and silver nanoparticles activity test. The formulation of research problems regarding the application of nanogold and silver nanoparticles to leprosy patients was as follows:

1. What was the result of the synthesis and characterization of nanogold and silver nanoparticles?

2. How were the results of the nanogold and silver nanoparticles activity test on leprosy patient patients in detail in the form of

a. What percentage of the average reduction in wound width occurred in the treatment group after the application of nanogold and silver nanoparticles during the study, compared to the control group.

b. What percentage of the average pain reduction occurred in the treatment group after the application of nanogold and silver nanoparticles during the study, compared to the control group.

c. What was the average body temperature of the treatment group after applying nanogold and silver nanoparticles during the study, compared to the control group?

d. What was the blood pressure of the treatment group after the application of nanogold and silver nanoparticles during the study, compared to the control group?

e. What was the heart rate of the treatment group after applying nanogold and silver nanoparticles during the study, compared to the control group?

f. What percentage of the skin surface softness of the treatment group after applying nanogold and silver nanoparticles during the study, compared to the control group.

\section{RESEARCH METHODS}

The tools used for synthesis was various glass equipment including beaker glasses, measuring cups, measuring flasks, pipette, and heater. The material used was mother liquor $\mathrm{HAuCl}_{4}$ and $\mathrm{AgNO}_{3} 1000 \mathrm{ppm}$, sodium citrate, and distilled water. Medical equipment used in the nanogold and silver nanoparticles activity test involving patients of leprosy patients was a blood pressure measuring device, heart rate measuring device, thermometer, and camera. In addition, a questionnaire was prepared in the form of questions about the pain felt and the smoothness of the skin surface felt by patients.

\section{EXPERIMENTAL SETUP}

\section{A. Synthesis and Characterization Methods}

The synthesis was carried out using the Bottom-Up method, which was the process of making nanomaterials from smaller size base material to larger nanomaterial. The basic material of synthesis was Au3+ (HAuCl4) sized 10-12 $\mathrm{m}$ (small) into nanogold at 10-9 m (large). Similarly, the synthesis of silver nanoparticles from $\mathrm{Ag}+(\mathrm{AgNO} 3)$ material into silver nanoparticles.

Characterization of synthesis results used UVVisible instruments to determine nanogold and silver nanoparticles UV light absorption at certain wavelengths. Other characterizations used the Transmission Electron Microscope (TEM) instrument to determine the size of nanomaterial atomic particles

\section{B. Activity Test Method}

As much as 60 patients were divided into two groups consisted of 30 people, respectively. One group has applied a combination of nanogold and silver nanoparticles together with consumption of leprosy drugs (treatment group). The other group was leprosy patients who continue to consume leprosy drugs without nanogold and silver nanoparticles (control group). Various medical indicators in the treatment and control groups were recorded every 2 weeks for 3 months by medical experts. Medical indicators recorded included recovery of wounds (width and pain), body temperature, blood pressure, heartbeat and softness of the skin surface of patients in leprosy patients.

\section{RESULTS AND DISCUSSION}

\section{A. Synthesis Results}

Nanogold synthesis with the basic ingredients $\mathrm{HAuCl} 4$ with reducing sodium citrate produced colloids coloured red to grape red. Silver nanoparticles were produced by synthesis with base material of silver nitrate forming a yellow colloid. Nanogold easily changed colour and aggregation so colloid colours turned from purple to grey. Silver nanoparticles were more stable which had cloudy yellow to grey yellow [2]. The colour of the nanogold colloid and silver nanoparticles can be observed in Fig. 1. 


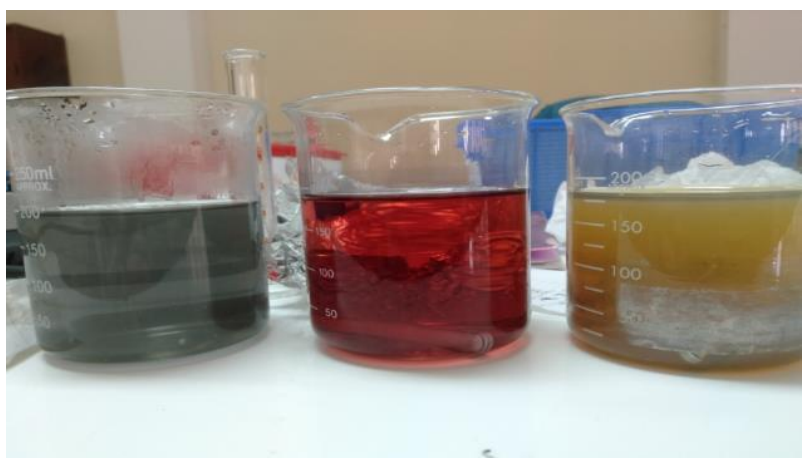

Figure 1. Red Colloidal Gold (left) and Yellow Colloidal Silver (right) Characterization Results

\section{B. UV Instruments}

UV-Visible uptake of nanogold colloids occurred at a wavelength of $517-520 \mathrm{~nm}$. The higher the nanogold concentration, the higher the absorption of UV-Visible light, as shown in Table 1 and Figure 2.

TABLE I. UV-VIS ABSORPTION NANOGOLD AT VARIOUS CONCENTRATION

\begin{tabular}{|l|c|c|c|}
\hline No & $\begin{array}{c}\text { Concentrate } \\
(\mathbf{p p m})\end{array}$ & $\begin{array}{c}\text { Wavelength Maximum } \\
\boldsymbol{\lambda}(\mathbf{n m})\end{array}$ & Absorbance \\
\hline 1 & 5 & 517.00 & 0.212 \\
\hline 2 & 10 & 517.50 & 0.369 \\
\hline 3 & 15 & 518.00 & 0.521 \\
\hline 4 & 20 & 520.00 & 0.668 \\
\hline 5 & 25 & 518.00 & 0.682 \\
\hline
\end{tabular}

UV-Visible absorption of combined silver nanoparticles and nanogold at various concentrations is shown in Table 2. The greater the concentration of nanogold the greater the absorbance, but the maximum wavelength decreased or shifted towards shorter wavelengths of 429-433 nm [15]. This can be observed in Figure 3.

TABLE II. UV-VIS ABSORBANCE COMBINATION SILVER NANOPARTICLES WITH NANOGOLD AT VARIOUS CONCENTRATION

\begin{tabular}{|c|c|c|c|}
\hline No & $\begin{array}{c}\text { Concentrate } \\
(\mathbf{p p m})\end{array}$ & $\begin{array}{c}\text { Wavelength } \\
\text { Maximum } \boldsymbol{\lambda}(\mathbf{n m})\end{array}$ & Absorbance \\
\hline 1 & 5 & 433.00 & 0.464 \\
\hline 2 & 10 & 431.00 & 0.460 \\
\hline 3 & 15 & 434.00 & 0.521 \\
\hline 4 & 20 & 432.50 & 0.515 \\
\hline 5 & 25 & 429.50 & 0.544 \\
\hline
\end{tabular}

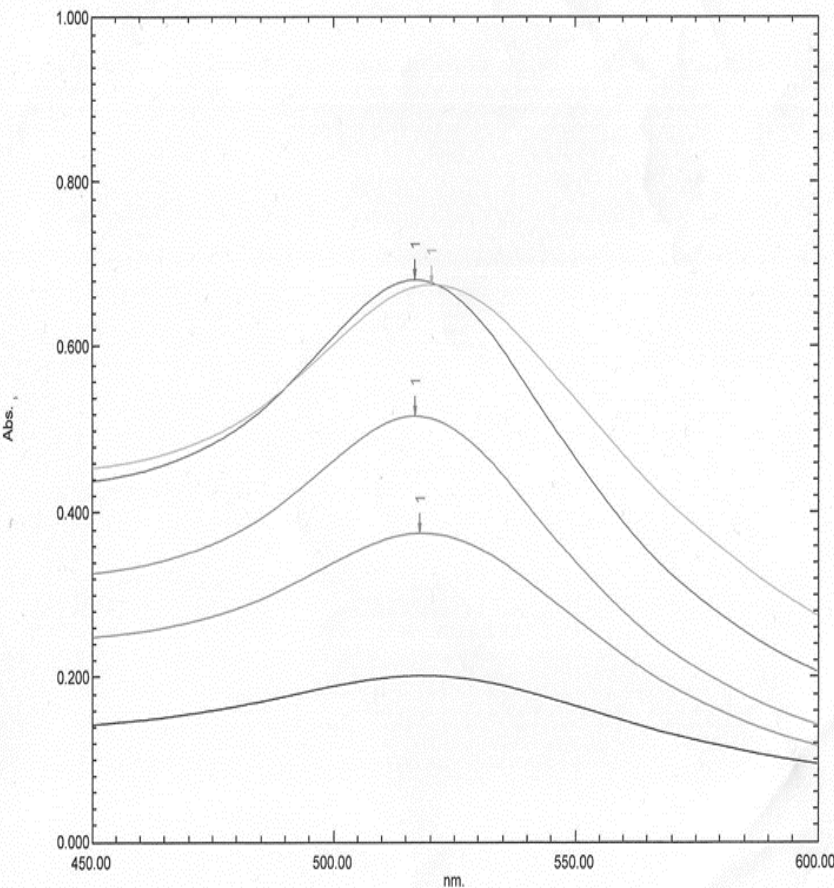

Figure 2. UV-Visible Spectrogram of Nanogold at Various Concentration

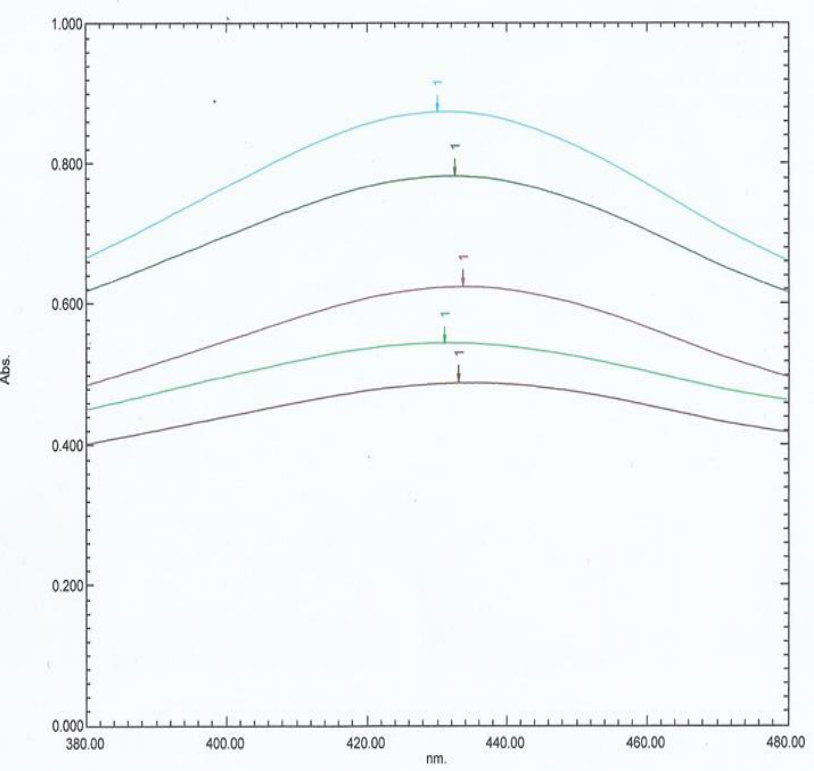

Figure 3. UV-Visible Spectra of Combination Silver nanoparticles and Nanogold at Various Concentration. 


\section{TEM Analysis}

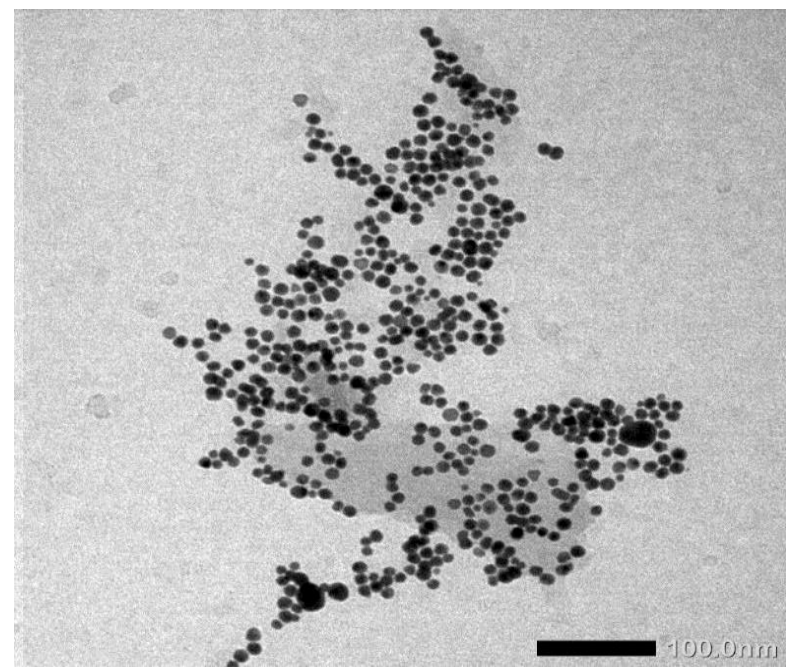

Figure 4. TEM of Nanogold

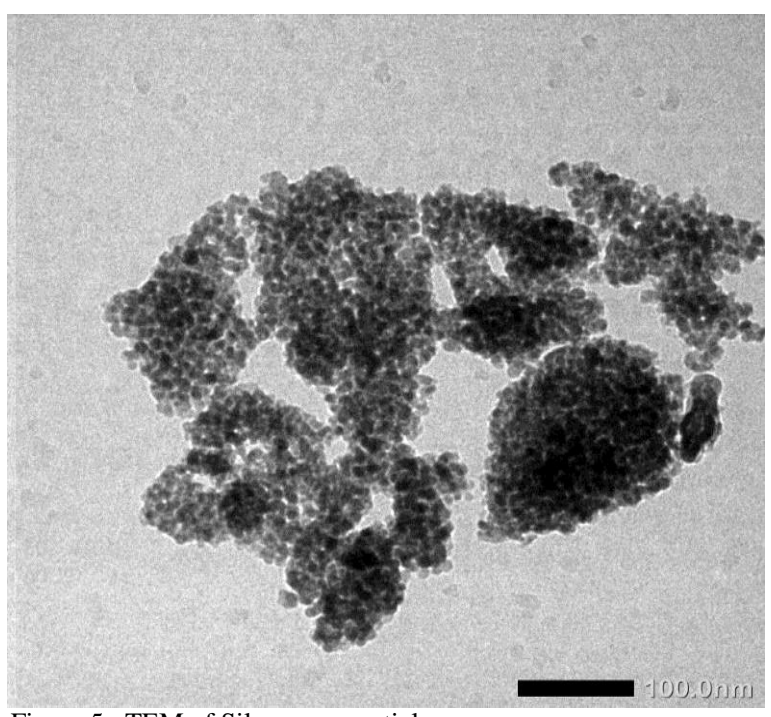

Figure 5. TEM of Silver nanoparticles

\section{Result of Activity Test}

The results of the gold-silver nanoparticles activity test showed that patients treated with gold-silver nanoparticles recovered faster than patients without treatment. In more detail, each indicator could be seen in Table 3 and Table 4 and also explained as follows:

1. The width of the wound treatment group was decreased to $80 \%$ during 3 months the application of nanogoldsilver nanoparticles to accompany conventional leprosy drugs. The wound width of the control group decreased only to $50 \%$ after 3 months. Thus, nanoparticles played a very good role in accelerating wounds healing.

2. The pain experienced by treatment group patients decreased by $80 \%$ after 3 months application of nanogold-silver nanoparticles to accompany conventional leprosy drugs. The pain of the control group decreased by only $50 \%$ for 3 months. Thus nanogold-silver nanoparticles played a good role in reducing pain.

3. The body temperature of the treatment group and the control group improved towards a normal body temperature of healthy people to be $37^{\circ} \mathrm{C}$. Thus nanogold-silver nanoparticles could act to normalize body temperature as conventional.

4. Blood Pressure patients in the treatment group and the control group improved to normal blood pressure. Thus, both nanogold-silver nanoparticles and conventional leprosy drugs normalized blood pressure.

5. The heartbeat of patients in the treatment and the control group showed a decrease in approaching normal heart rate. Thus, both silver nanoparticles-nanogold and conventional leprosy drugs normalize the heart rate.

6. The softness of the control group patients' skin increased to $70 \%$, namely from rough skin $(20 \%$ softness) to smooth with $90 \%$ softness. This was better than the control group. Thus, the nanoparticles had a very good role in smoothing the skin of Volunteer.

TABLE III

ACTIVITY TEST NANOGOLD-SILVER NANOPARTICLES EVERY 2 WEEKS (TREATMENT GROUP)

\begin{tabular}{|c|l|c|c|c|c|c|c|c|}
\hline No & $\begin{array}{l}\text { Medical } \\
\text { Indicator }\end{array}$ & $\begin{array}{c}\text { Data } \\
\mathbf{0}\end{array}$ & $\begin{array}{c}\text { Data } \\
\mathbf{1}\end{array}$ & $\begin{array}{c}\text { Data } \\
\mathbf{2}\end{array}$ & $\begin{array}{c}\text { Data } \\
\mathbf{3}\end{array}$ & $\begin{array}{c}\text { Data } \\
\mathbf{4}\end{array}$ & Data5 & $\begin{array}{c}\text { Data } \\
\mathbf{6}\end{array}$ \\
\hline 1 & $\begin{array}{l}\text { Wound } \\
\text { width }\end{array}$ & $100 \%$ & 90 & 80 & 70 & 50 & 30 & 20 \\
$\%$ & $\%$ & $\%$ & $\%$ & $\%$ \\
\hline 2 & Pain (sick) & $100 \%$ & $80 \%$ & $60 \%$ & $50 \%$ & $40 \%$ & $30 \%$ & $\begin{array}{c}20 \\
\%\end{array}$ \\
\hline 3 & $\begin{array}{l}\text { Temperatur } \\
\mathrm{e}\left({ }^{\circ} \mathrm{C}\right)\end{array}$ & 39 & 39 & 38.5 & 38.5 & 38 & 37 & 37 \\
\hline 4 & $\begin{array}{l}\text { Blood } \\
\text { Pressure }\end{array}$ & $\begin{array}{c}140 / 11 \\
0\end{array}$ & $\begin{array}{c}130 / 11 \\
0\end{array}$ & $\begin{array}{c}130 / 11 \\
0\end{array}$ & $\begin{array}{c}120 / 10 \\
0\end{array}$ & $\begin{array}{c}120 / 10 \\
0\end{array}$ & $\begin{array}{c}120 / 10 \\
0\end{array}$ & $\begin{array}{c}110 / 10 \\
0\end{array}$ \\
\hline 5 & Heart Beat & 90 & 89 & 88 & 82 & 82 & 80 & 80 \\
\hline 6 & $\begin{array}{l}\text { Skin } \\
\text { Softness }\end{array}$ & $20 \%$ & $30 \%$ & $50 \%$ & $60 \%$ & $80 \%$ & $90 \%$ & $90 \%$ \\
\hline
\end{tabular}

TABLE IV

DATA OF CONTROL GROUP

\begin{tabular}{|c|l|c|c|c|c|c|c|c|}
\hline No & $\begin{array}{l}\text { Medical } \\
\text { Indicator }\end{array}$ & $\begin{array}{c}\text { Data } \\
\mathbf{0}\end{array}$ & $\begin{array}{c}\text { Data } \\
\mathbf{1}\end{array}$ & $\begin{array}{c}\text { Data } \\
\mathbf{2}\end{array}$ & $\begin{array}{c}\text { Data } \\
\mathbf{3}\end{array}$ & $\begin{array}{c}\text { Data } \\
\mathbf{4}\end{array}$ & Data5 & $\begin{array}{c}\text { Data } \\
\mathbf{6}\end{array}$ \\
\hline 1 & $\begin{array}{l}\text { Wound } \\
\text { width }\end{array}$ & $100 \%$ & $\begin{array}{c}90 \\
\%\end{array}$ & $\begin{array}{c}85 \\
\%\end{array}$ & $\begin{array}{c}80 \\
\%\end{array}$ & $\begin{array}{c}70 \\
\%\end{array}$ & $\begin{array}{c}60 \\
\%\end{array}$ & $\begin{array}{c}50 \\
\%\end{array}$ \\
\hline 2 & Pain (sick) & $100 \%$ & $100 \%$ & $90 \%$ & $80 \%$ & $70 \%$ & $60 \%$ & $\begin{array}{c}50 \\
\%\end{array}$ \\
\hline 3 & $\begin{array}{l}\text { Temperatur } \\
\text { e }\left({ }^{\circ} \mathrm{C}\right)\end{array}$ & 39 & 38.5 & 38.5 & 38 & 38 & 37 & 37 \\
\hline 4 & $\begin{array}{l}\text { Blood } \\
\text { Pressure }\end{array}$ & $\begin{array}{c}140 / 11 \\
0\end{array}$ & $\begin{array}{c}140 / 11 \\
0\end{array}$ & $\begin{array}{c}130 / 11 \\
0\end{array}$ & $\begin{array}{c}130 / 11 \\
0\end{array}$ & $\begin{array}{c}120 / 11 \\
0\end{array}$ & $\begin{array}{c}120 / 10 \\
0\end{array}$ & $\begin{array}{c}110 / 10 \\
0\end{array}$ \\
\hline 5 & Heart Beat & 90 & 90 & 86 & 84 & 82 & 80 & 80 \\
\hline 6 & $\begin{array}{l}\text { Skin } \\
\text { Softness }\end{array}$ & $20 \%$ & $30 \%$ & $30 \%$ & $40 \%$ & $40 \%$ & $50 \%$ & $50 \%$ \\
\hline
\end{tabular}




\section{E. Discussion}

\section{a) Wound recovery}

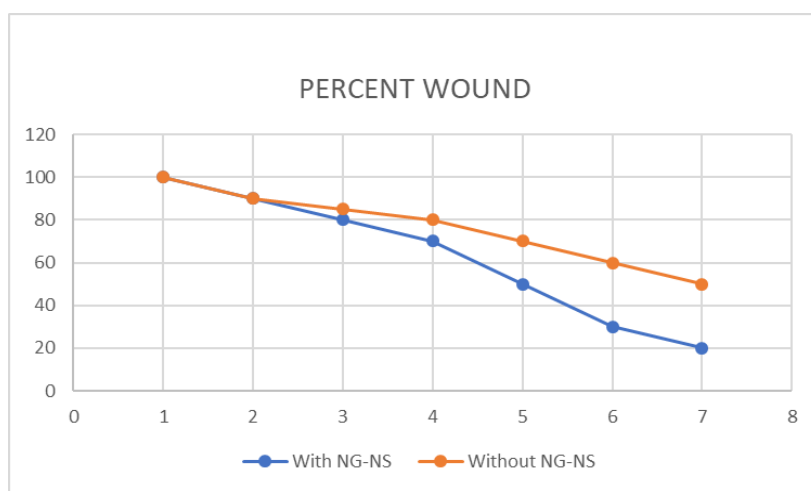

Figure 6. Percentage of wound healing in Volunteer.

Wound recovery could be observed from the decrease in the wound percentage in treatment and control group patients. Silver nanoparticles-nanogold could reduce wounds better than only using conventional leprosy drugs (Fig. 6). This was because nanogold played a role in wound closure by inducing faster collagen proliferation and synthesis [1]. Silver nanoparticles acted to kill microbes, thereby reducing damage due to microbial activity to tissues [15].

\section{b) Pain}

Decreased pain could be indicated from the lowering of pain percentage in treatment and control groups (without nanoparticles). Silver nanoparticles-nanogold could reduce injury better than just using conventional leprosy drugs (Fig. 7). This was because silver nanoparticles acted to kill microbes causing inflammation, resulting in faster pain decrease [15].

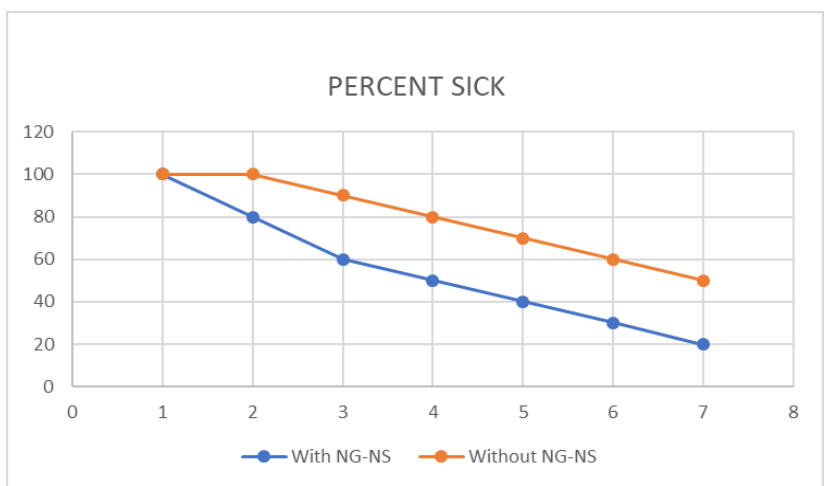

Figure 7. Percentage of pain in volunteer

\section{c) Body temperature}

The body temperature of patients with the treatment of silver nanoparticles nanogold and patients without treatment or control group underwent an insignificant decrease. Thus, both groups experienced normal body temperature recovery. This could be observed from Figure 8 where the blue line merges with the yellow line.

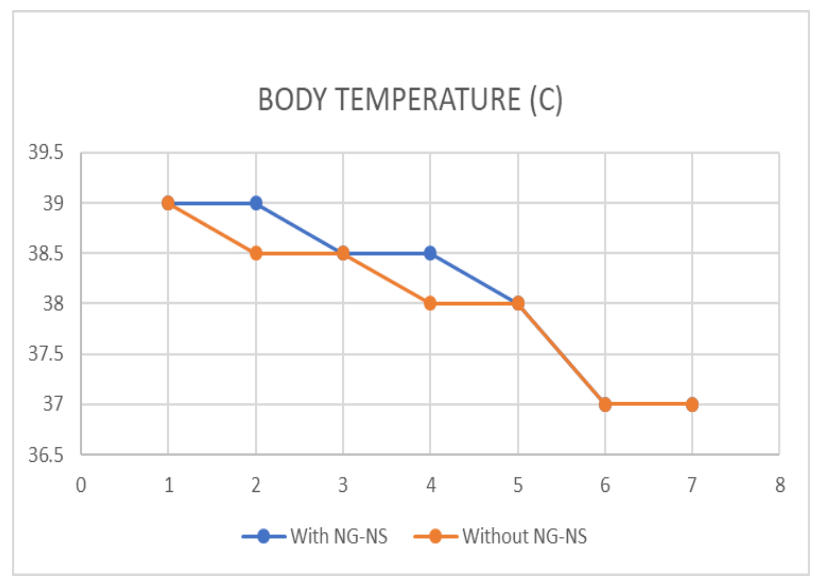

Figure 8 . The body temperature of patients

\section{d) Blood Pressure}

Voluntary blood pressure with the treatment of silver nanoparticles and nanogold and patients without treatment or control groups both underwent a slight decrease (Fig. 9). Thus, both groups both experienced normal recovery of blood pressure.

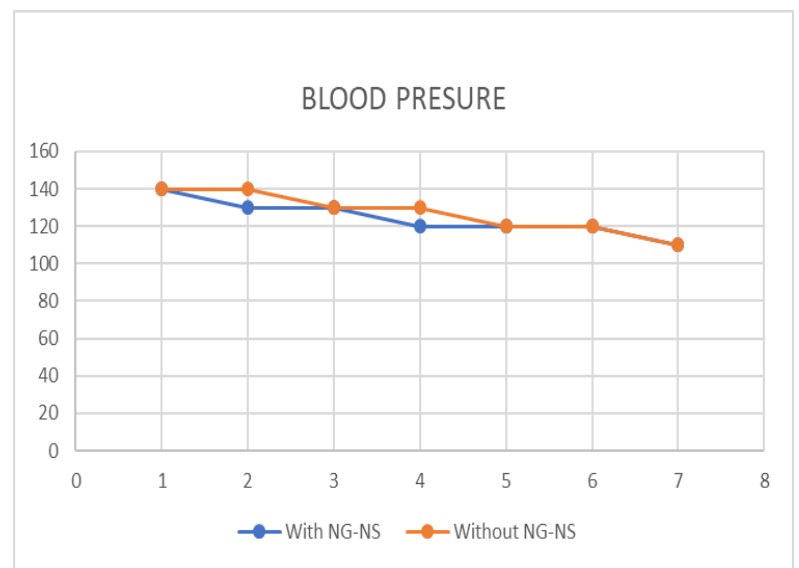

Figure 9. Blood Pressure of Volunteer

\section{e) Heart Beat}

Volunteer heart rate with the treatment of nanogold and silver nanoparticles patients without treatment or control group underwent an insignificant decrease (Fig. 10). Thus both the treatment group and the control group both underwent recovery in heart rate to normal.

f) Skin smoothness

Skin smoothness could be observed in the increased softness of the skin of the patients in the treatment group which was much higher than the control group (Fig. 11). This was because nanogold played a role in the process of cell proliferation and collagen synthesis which induced young, elastic and soft skin.

\section{CONCLUSION}

The combination of nanogold and silver nanoparticles could accelerate the healing process of leprosy patients with various criteria. Nanogold and silver nanoparticles can be relied upon for the treatment of several diseases and are essential ingredients of future drugs. 


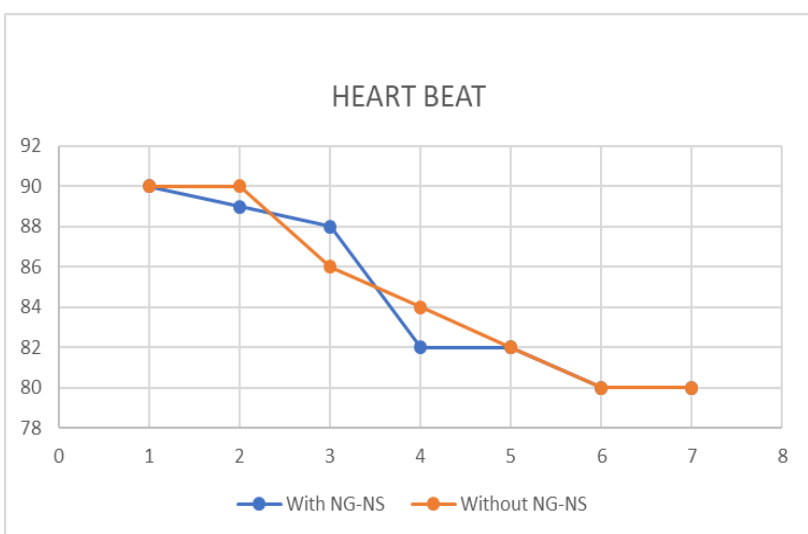

Figure 10. The heart rate of patients

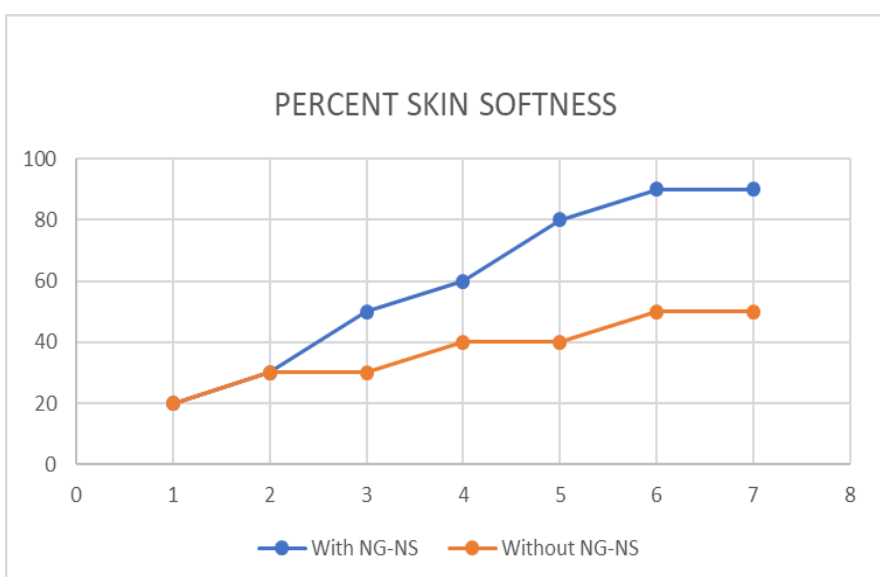

Figure 11. Percentage of skin smoothness in patients

\section{ACKNOWLEDGEMENT}

Thank you are conveyed to the Ministry of Research and Higher Education who have funded this activity included in the development research scheme in the 2019 budget year.

\section{REFERENCES}

[1] T. Taufikurohmah, et al., "Histology Study: Pre-clinic test of nanogold in Mus musculus skin, at fibroblast proliferation and collagen biosynthesis," Chem. Mat. Res., vol. 3, no. 5, pp. 55-60, 2013.

[2] T. Taufikurohmah, et al., "Activity test of nanogold for reduction of free radicals, a pre-assessment utilization nanogold in pharmaceutical as medicines and cosmetics," J. Mat. Sc. Eng. B, vol. 2, no.12, pp. 611-617, 2012.

[3] T. Taufikurohmah, et al., "The clinical test of nano gold cosmetic for recovering skin damage due to chemicals: special case," J. Phys.: Conference Series, vol. 947, no. 1, 2018.

[4] J, Hou, et al., "Tissue profiling by nanogold-mediated mass spectrometry and artificial neural networks in the mouse model of the hyperoxaluria," Sciencedirect vol. 1, no. 2, pp. 0-6, 2013.

[5] F.K. Alanazi, A.A. Radwan, and I.A. Alsarra, "Biopharmaceutical applications of nanogold," Saudi Pharm. J., vol. 18, no. 4, pp.179193, 2010.

[6] P. Pratim, et al., "In vivo and in vitro toxicity of nanogold conjugated snake venom protein toxin GNP-NKCT1," Toxic. Rep., vol. 1, pp.74-84, 2014.

[7] L.A. Dykman, and N.G. Khlebtsov, "Gold nanoparticles in biology and medicine: recent advances and prospects," Acta naturae, vol. 3, no. 2, pp.34-55, 2011.

[8] C. Carnovale, et al., "Size , shape and surface chemistry of nanogold dictate its cellular interactions, uptake and toxicity," J. Prog. Mat. Sc., 2016.

[9] T. Murai, et al., "Ultrastructural analysis of nanogold-labeled cell surface microvilli in liquid by atmospheric scanning electron microscopy and their relevance in cell adhesion," Int. J. Mol. Sc., vol. 14, no. 10, pp. 20809-20819, 2013.

[10] B.A. Katsnelson, et al., "Comparative in vivo assessment of some adverse bioeffects of equidimensional gold and silver nanoparticles and the attenuation of silver nanoparticles's effects with a complex of innocuous bioprotectors," Int. J. Mol. Sc., vol. 14, no. 2, pp.2449-2483, 2013.

[11] V. Sarsar, K.K. Selwal, and M.K. Selwal, "Potent antimicrobial agent and its biosynthesis Silver nanoparticles," vol. 13, no. 4, pp.546-554, 2014

[12] N. Podejmowanie, and T. Decyzji, "Silver nanoparticles - Making Difficult Decisions Obtaining nanomaterials," vol. 18, no. 2, 2011.

[13] J.H. Johnston, and T. Nilsson, "Nanogold and silver nanoparticles composites with lignin-containing cellulose fibres," J. Mat. Sc., 2012.

[14] K. Shameli, et al., "Investigation of antibacterial properties silver nanoparticles prepared via green method," Chem. Cent. J., vol. 6, no. 1 , pp. $1,2012$.

[15] T. Taufikurohmah, et al., "Stability of colloidal silver nanoparticles synthesized with variance silver ions as antimicrobial in cosmetic formulation," As. J. Chem., vol. 27, no.4, 2015.

[16] S. Leclerc, and K.J. Wilkinson, "Bioaccumulation of Silver nanoparticles by Chlamydomonas reinhardtii Nanoparticle or the Free Ion?", 2014.

[17] T. Taufikurohmah, et al., Proses Pembuatan Nanogold Menggunakan Matriks Gliserin Serta Penggunaannya Sebagai Salep Kulit dan Obat Luar, sudah bersertifikat, Sertifikat, 2017.

[18] T. Taufikurohmah, et al., Proses Pembuatan Nanogold Menggunakan Matriks Polivinil pirolidon (PVP) Serta Penggunaannya Dalam Formula obat Penyakit Lepra/Kusta 